\title{
How Many Artists Are There in the Family?: The Career of Montreal Painter Regina Seiden (1897-1991)
}

\section{Barbara Meadowcroft}

Volume 25, numéro 1-2, 1998

Producing Women

Ces femmes qui produisent ...

URI : https://id.erudit.org/iderudit/1071615ar

DOI : https://doi.org/10.7202/1071615ar

Aller au sommaire du numéro

Éditeur(s)

UAAC-AAUC (University Art Association of Canada | Association d'art des universités du Canada)

ISSN

0315-9906 (imprimé)

1918-4778 (numérique)

Découvrir la revue

Citer cet article

Meadowcroft, B. (1998). How Many Artists Are There in the Family?: The Career of Montreal Painter Regina Seiden (1897-1991). RACAR : Revue d'art canadienne / Canadian Art Review, 25(1-2), 73-83.

https://doi.org/10.7202/1071615ar

\section{Résumé de l'article}

Regina Seiden exposa professionnellement pendant quinze ans, soit de 1915 à 1930. Elle participa aux expositions annuelles de l'Art Association of Montreal et de la Royal Canadian Academy et à celles, plus internationales, de la British Empire Exhibition de Wembley en Angleterre (1924 et 1925). La production de Seiden a été reconnue par la critique, notamment par Albert Laberge du journal, La Presse. L'artiste cessa d'exposer peu après son mariage avec le peintre Eric Goldberg. Son retrait trop rapide de la scène artistique l'a condamnée à un oubli total par l'histoire de l'art canadienne.

Seiden est née en 1897 dans la petite ville de Rigaud au Québec. Ses parents étaient des Juifs originaires de l'Empire austro-hongrois. Comme jeune Juive éduquée dans les écoles catholiques et, plus tard, avec les étudiants anglo-protestants de l'Art Association of Montreal, elle occupe une place à part parmi ses contemporains. Elle reçut une excellente formation artistique sous la direction de William Brymner, le directeur de l'école de l'AAM, mais elle s'est peu liée avec les autres étudiants, possiblement à cause de leurs différences culturelles. Parmi ses consoeurs de l'AAM, nombreuses furent celles, comme Anne Savage, Lilias Torrance Newton et Prudence Heward, qui firent des carrières distinguées, soutenues par les amitiés développées à l'AAM.

Comme Prudence Heward et Lilias Torrance Newton, Regina Seiden s'intéressait surtout à la figure humaine et au portrait; cette étude examine six de ses oeuvres. J'analyse Dora (1923), Girl Washing Dishes on a Farm, Saint-Eustache, Québec (ca. 1923), entre autres, sous l'angle de la perception changeante de la place des femmes dans la société; je discute de Nudes (1925), une étude de deux femmes nues, dans le contexte des attitudes puritaines envers le corps qui prévalaient à l'époque et en rapport avec le Nude in a Studio de Lilias Torrance Newton et Sleeping Woman de Randolph Hewton.

En 1927, Seiden rencontre Eric Goldberg à Paris et si elle peint toujours au début de leurs fréquentations, elle cessera peu après son mariage. Pendant tout le reste de sa vie, Seiden se dévoua à la promotion de la carrière de son mari. Lorsque ce dernier mourut en 1969, elle fut inconsolable et ce n'est que plus tard qu'elle se remit à peindre mais elle n'avait alors plus l'énergie ni la motivation nécessaires pour poursuivre. La carrière avortée de Seiden reste exemplaire des difficultés auxquelles les femmes devaient faire face (et, d'une certaine manière, auxquelles elles doivent faire face encore aujourd'hui) pour réconcilier leur vie d'épouse et d'artiste.
Tous droits réservés @ C UAAC-AAUC (University Art Association of Canada | Association d'art des universités du Canada), 2001
Ce document est protégé par la loi sur le droit d'auteur. L’utilisation des services d’Érudit (y compris la reproduction) est assujettie à sa politique d'utilisation que vous pouvez consulter en ligne.

https://apropos.erudit.org/fr/usagers/politique-dutilisation/ 


\title{
How Many Artists Are There in the Family?: The Career of Montreal Painter Regina Seiden (|897-199|)
}

\author{
Barbara Meadowcroft, Simone de Beauvoir Institute, Concordia University
}

R egina Seiden exposa professionnellement pendant quinze ans, soit de 1915 à 1930. Elle participa aux expositions annuelles de l'Art Association of Montreal et de la Royal Canadian Academy et à celles, plus internationales, de la British Empire Exhibition de Wembley en Angleterre (1924 et 1925). La production de Seiden a été reconnue par la critique, notamment par Albert Laberge du journal, La Presse. L'artiste cessa d'exposer peu après son mariage avec le peintre Eric Goldberg. Son retrait trop rapide de la scène artistique l'a condamnée à un oubli total par l'histoire de l'art canadienne.

Seiden est née en 1897 dans la petite ville de Rigaud au Québec. Ses parents étaient des Juifs originaires de l'Empire austro-hongrois Comme jeune Juive éduquée dans les écoles catholiques et, plus tard, avec les étudiants anglo-protestants de l'Art Association of Montreal, elle occupe une place à part parmi ses contemporains. Elle reçut une excellente formation artistique sous la direction de William Brymner, le directeur de l'école de l'AAM, mais elle s'est peu liée avec les autres étudiants, possiblement à cause de leurs différences culturelles. Parmi ses consoeurs de l'AAM, nombreuses furent celles, comme Anne Savage, Lilias Torrance Newton et Prudence Heward, qui firent des carrières distinguées, soutenues par les amitiés développées à l'AAM. Comme Prudence Heward et Lilias Torrance Newton, Regina Seiden s'intéressait surtout à la figure humaine et au portrait; cette étude examine six de ses oeuvres. J'analyse Dora (1923). Girl Washing Dishes on a Farm, Saint-Eustache, Québec (ca. 1923), entre autres, sous l'angle de la perception changeante de la place des femmes dans la société; je discute de Nudes (1925), une étude de deux femmes nues, dans le contexte des attitudes puritaines envers le corps qui prévalaient à l'époque et en rapport avec le Nude in a Studio de Lilias Torrance Newton et Sleeping Woman de Randolph Hewton.

En 1927, Seiden rencontre Eric Goldberg à Paris et si elle peint toujours au début de leurs fréquentations, elle cessera peu après son mariage. Pendant tout le reste de sa vie. Seiden se dévoua à la promotion de la carrière de son mari. Lorsque ce dernier mourut en 1969, elle fut inconsolable et ce n'est que plus tard qu'elle se remit à peindre mais elle n'avait alors plus l'energie ni la motivation nécessaires pour poursuivre. La carrière avortée de Seiden reste exemplaire des difficultés auxquelles les femmes devaient faire face (et, d'une certaine manière, auxquelles elles doivent faire face encore aujourd'hui) pour réconcilier leur vie d'épouse et d'artiste.
$\mathrm{T}$

he portrait of Regina Seiden by her husband Eric Goldberg shows a young woman working at her easel (fig. 1). Ironically, the image celebrates a career that is about to end. The woman producer is becoming the woman produced. Goldberg's portrait was painted in 1928, the year he and Seiden were married. It may have been intended as a gift for his bride, as it is signed only "E. Eric - 28." But even as he celebrates her as a painter, Goldberg obscures her identity by placing his signature on the portrait she is painting. Within a year of the wedding Seiden gave up painting, submerging her career in that of her husband.

Regina Seiden's exhibiting career lasted fifteen years, 191530. Like many Montreal painters of this period, and unlike the Group of Seven, Seiden was primarily interested in the human figure and portraiture. The inclusion of her portrait Dora (1923) in the recent exhibition, Peindre à Montréal, 1915-1930, suggests affinities with Montreal painters like Prudence Heward, Lilias Torrance Newton and Edwin Holgate. ${ }^{1}$

While still a student at the Art Association of Montreal (AAM), Regina Seiden exhibited at the AAM Spring Exhibitions and the annual shows of the Royal Canadian Academy (RCA). She contributed to the 1924 and 1925 British Empire Exhibitions at Wembley, England, the shows that drew international attention to Canadian painting, ${ }^{2}$ and the 1927 Exposition d'art canadien at the Musée du Jeu de Paume in Paris. She sold three paintings to the National Gallery of Canada - a feat for any young artist, although perhaps less exceptional in the 1920s when the National Gallery was building up its Canadian collection. ${ }^{3}$ Her work was admired by connoisseurs and critics, including Albert Laberge of La Presse, who dubbed Seiden "l'une des mieux douées parmi les artistes de la métropole." ${ }^{4}$

Despite these achievements, Regina Seiden stopped exhibiting soon after she married. Although many women artists have abandoned their careers or lessened their productivity after marriage, Seiden's success and commitment to painting make her retirement surprising. ${ }^{5}$ Since 1930 she has been largely overlooked by art historians and curators. This essay is a first attempt to write Seiden back into Canadian art history.

Regina Seiden was born in the small town of Rigaud, Quebec, on 4 July 1897. The Seiden family - Wolfe Seiden, his wife Jente Rosenbaum and their three sons - came to Canada from Galicia around 1890 to escape the pogroms in what was then part of the Austro-Hungarian Empire. ${ }^{6}$ In 1895, the family settled in Rigaud where Wolfe Seiden opened a general store. After his death in 1899 , Jente Seiden continued to run the store with the help of her sons, until 1905 when the family moved to Montreal.

As a child, Regina Seiden was exposed to three cultures: 
Figure I. Eric Goldberg, Portrait of Regina Seiden, 1928. Watercolour and pastel over graphite on wove paper, $38.2 \times 51.0$ cm. Ottawa, National Gallery of Canada. Gift of Regina Seiden Goldberg, Montreal, 1980 (Photo: National Gallery of (anada).

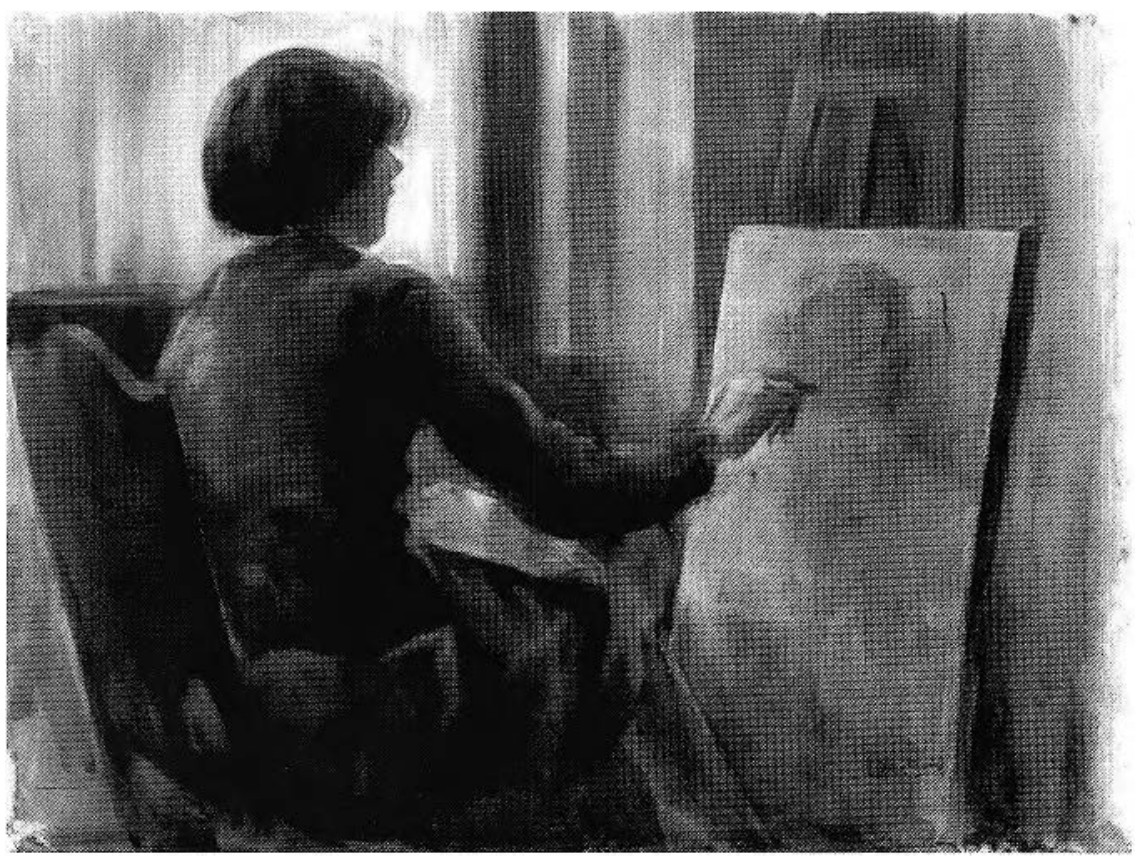

classes in the open air. But perhaps most important of all, he imbued his students with a sense of vocation. As Seiden's fellow pupil Anne Savage remarked, he gave them a sense of the "terrific importance" of being involved with the world of art. ${ }^{10}$

The AAM school charged substantial fees and attracted mainly female students. ${ }^{11}$ Men had the option, denied to women, of attending free courses sponsored by the Royal Canadian Academy. Although Brymner encouraged his talented female scudents to become professional artists, the general perception at the time was that women studied art to improve their taste or embellish their homes, not to become professionals. Such, for example, were the expectations of the Quebec Government when it established the Montreal École des Beaux Arts in $1923 . .^{12}$

Regina Seiden and her fellow students

Yiddish, French-Canadian and Irish. Although the Seidens were the only Jews in Rigaud, they maintained their religious traditions, keeping a kosher table and celebrating the Jewish holidays.

Regina and her older sister, Antonia (b. 1895), attended the English class of a predominantly French convent school. The only Jews in the school, the Seiden girls were excused from religious observance, which may only have emphasized their sense of difference. According to Antonia, it was on holidays like Christmas and St Patrick's day that they felt particularly excluded.

In Montreal, the Seiden girls attended the Académie MarieRose, a private French school run by a Catholic order. Historian Marie-Paule Malouin, who has studied the Académie, remarks that the pedagogy was directed toward preparing the girls for their roles as wives and mothers. ${ }^{7}$ Although this was the orientation of most girls' schools at the time, the message was reinforced at the Académie by the Catholic ideology which permeated even the content of the teaching. ${ }^{8}$

Regina Seiden was encouraged to paint by the nuns and by her mother, a cultivated woman. In a memoir written in the 1980 s, Seiden says that she decided to become an artist at the age of twelve, after visiting the Art Association of Montreal (AAM) with her mother. ${ }^{?}$ In 1913, she gave up formal education to train as a painter at the AAM school.

William Brymner, Director of the AAM classes from 1886 to 1921 , became a sort of father figure to the adolescent Seiden. A forceful personality and inspiring teacher, he stressed the importance of intelligent observation and organized sketching had few female role models. They saw paintings by women in the Spring Exhibitions, but few, if any, in the AAM's permanent collection or loan exhibitions. ${ }^{13}$ In the classroom and in his public lectures, Brymner focused on the various schools of painting. ${ }^{14}$ This approach to art history, as Griselda Pollock and others have shown, has tended to marginalize women painters and to foster the myth of the artist as male genius. ${ }^{15}$ In the absence of female role models, the students mentored each other.

Seiden's classmates included many exceptionally talented women. Prudence Heward, Anne Savage, Lilias Torrance Newton, Sarah Robertson and Kathleen Morris all had successful exhibiting careers. These painters met at the AAM and forged friendships that lasted all their lives. Now known as the Beaver Hall women, they exhibited together, critiqued each orher's work, and formed a valuable support group in the male-oriented art world. ${ }^{16}$

Unlike the Beaver Hall women, Regina Seiden did not form any lasting friendships while at the AAM school. She contributed to the Beaver Hall Group exhibitions in 1921 and 1922, but subsequently had little contact with the Beaver Hall women. ${ }^{17}$ Cultural differences may have been partly responsible for this lack of intimacy, as most of the students were AngloProtestants. During the First World War, which broke out in Seiden's second year at the AAM, the brothers of the Beaver Hall women were fighting for the British Empire, while Seiden's Austro-Hungarian relatives supported the Germans. ${ }^{18}$

For six years Seiden focused on her studies, winning a scholarship in 1915 that provided her with two years free tuition. 
Figure 2. Regina Seiden, Portrait, 1919. Oil on canvas, $76.5 \times 66.4 \mathrm{~cm}$. Ottawa, National Gallery of Canada. Purchased, 1919 (Photo: National Gallery of Canada).

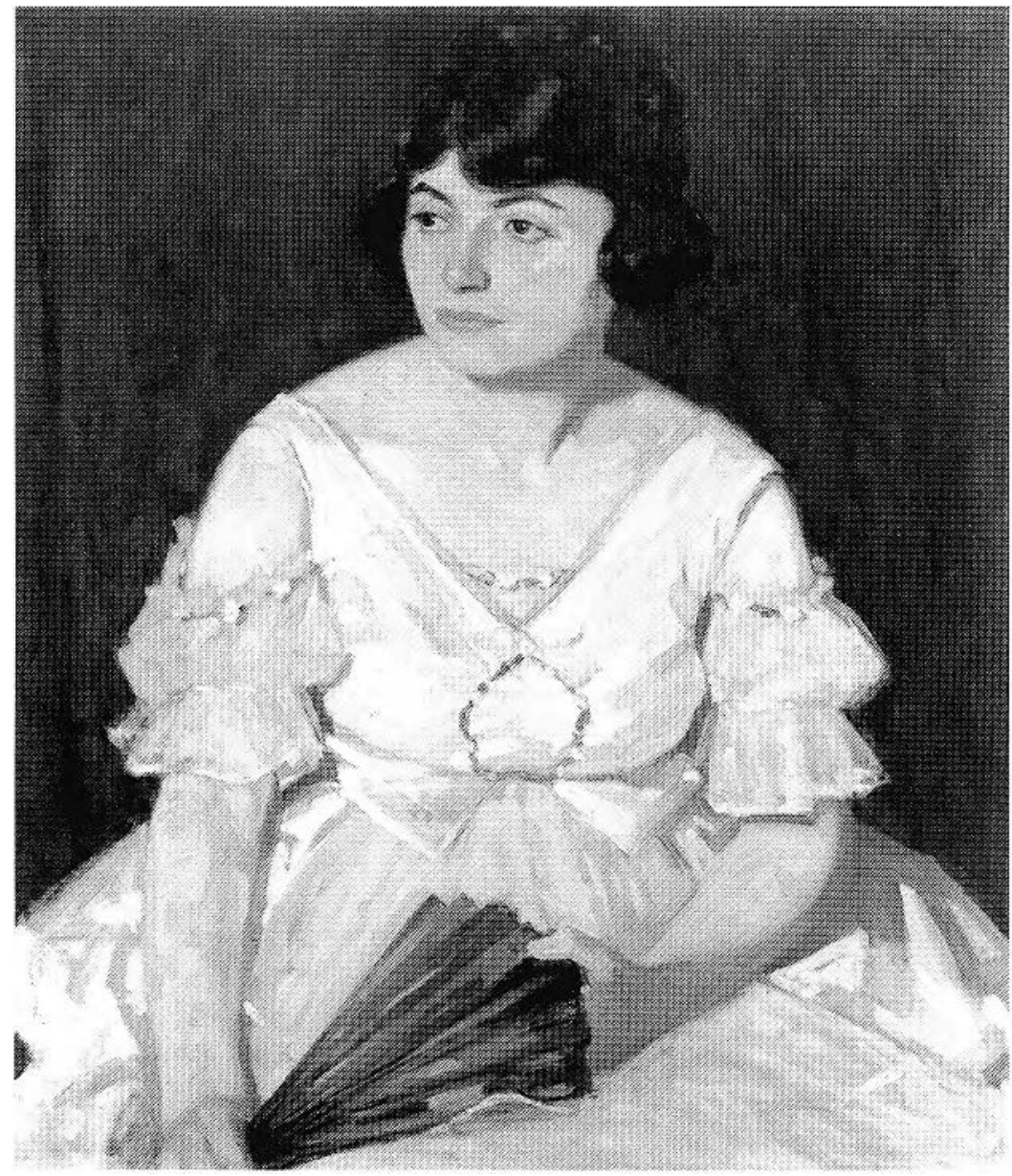

Their presence was justified on the ideological level by a discourse of patriotic sacrifice; the women were temporarily suspending their "femininity" to help the war effort. ${ }^{22}$ But by late 1919 when Seiden's Portrait was shown, a backlash against women in the work force had begun. A letter to the Toronto Evening Telegram quotes unemployment figures and takes aim at working women, saying, ". . . make these women give up their jobs and tend to their home affairs." 23 To men anxious about women's intrusion into traditionally male jobs, Portrait may have suggested a welcome return to "normal" (i.e. stereotypical) gender roles.

On the advice of William Brymner, Regina Seiden went to Paris in 1921 to continue her training. Going abroad was a big step for Seiden since, by her own admission, she had never been away from home before. ${ }^{24}$ Financed by her brothers, she enrolled in the women's section of the Académie Julian. While there, she met some American students with whom she rented a studio. Later, they travelled together to Venice and Florence, where Seiden sketched outdoors. Old Palace, Venice, exhibited at the AAM Spring Exhibition in 1923, was described in La Presse as "une superbe impression de la ville des gondoles." 25

Seiden returned to Montreal in the late summer of 1922. The four-year interval before her next European trip was her most productive pe-

In 1919, she won the Robert Reford prize for the best student painting. Later that year, the National Gallery bought Seiden's Portrait from the RCA exhibition, the only purchase the Gallery made from that exhibition (fig. 2). ${ }^{19}$

Portrait (1919) shows a young Jewish woman, Rae Kirsch (Mrs. R. Rosenthal), a friend of the Seiden family, wearing a pink, low-cut evening dress. The figure, cropped at the waist, occupies most of the canvas, conveying a strong sense of the sitter's presence. She leans forward, her head turned slightly to the left, as though listening attentively, while her hands toy with a fan. This image, which associates the sitter with the traditional occupations of young girls - parties and mating rituals may have had a special appeal in 1919 as a corrective to the image of the female war worker. Mabel May's painting, Women Making Shells, and sculptures of women labourers by Florence Wyle and Frances Loring were shown in the Canadian War Memorial Fund Exhibition earlier that year. ${ }^{20}$

During the war, as Kristina Huneault and others have remarked, photographs of female munitions workers focused public attention on the presence of women in the work force. ${ }^{21}$ riod. She found a room on McGill College Avenue for ten dollars a month, which she used as a studio. Here she painted her best-known works, including Old Immigrant Woman (fig. 3) and Dora (fig. 4).

In Old Immigrant Woman (1922) Seiden forges a link with her cultural past. She had visited her mother's family in Vienna while abroad and may have chosen the model because of a sympathy, conscious or unconscious, with her European ancestors. The sitter is wearing a black shawl over her head and shoulders in the manner of a European peasant. Her lined face and firmly set mouth suggest that she may have had a hard life, but she sits straight-backed and dignified, defying our pity. The dark, sober dress and the lack of accessories focus the viewer's attention on the model's care-worn face and suggest that Seiden was interested in the common humanity of her subject rather than in portraying her as a "picturesque" or "exotic" other. ${ }^{26}$

Although Seiden called the portrait simply "Old Woman" when she exhibited it in 1922, the sitter's features and costume would have identified her European origins. To the Canadian Jewish Review she was an "old Jewish woman," thus an immi- 
Figure 3. Regina Seiden, Old Immigrant Woman, 1922. Oil on canvas, $91.4 \times 71.1 \mathrm{~cm}$. Hamilton, Art Gallery of Hamilton. Presented in tribute to Mr. and Mrs. Goldblatt by their children, 1961 (Photo: Art Gallery of Hamilton).

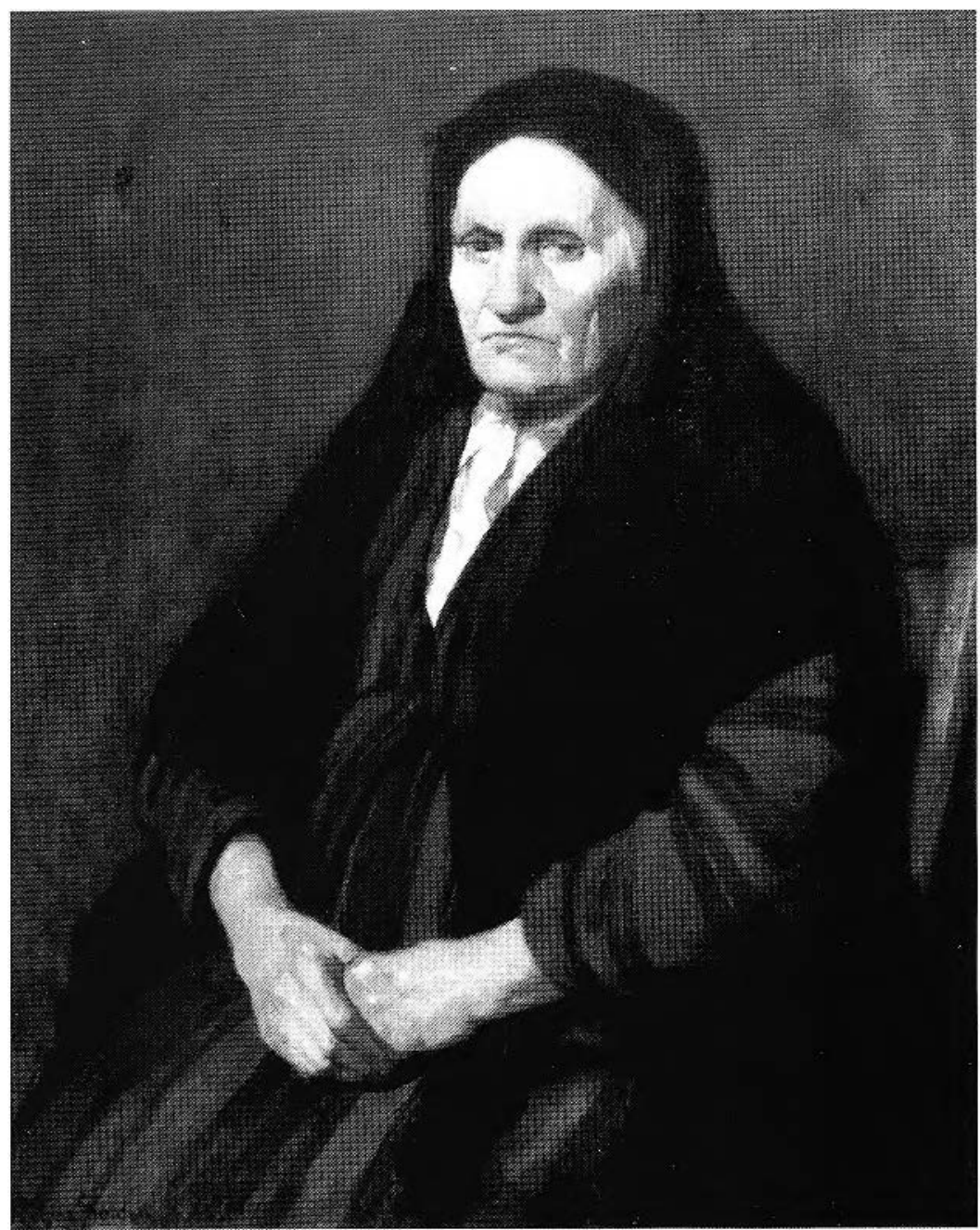

grant, since Jews only began arriving in Montreal in significant numbers at the turn of the century. ${ }^{27}$

Immigration was a hotly debated issue in the early 1920s. Anti-immigrant feelings were common, partly because of the scarcity of jobs during the post-war depression, but also because European immigrants were perceived as a threat to Canada's British character. The Immigration Act of 1919 reflected the government's wish to restrict the numbers of non-Anglo-Saxons entering the country. ${ }^{28}$ But within a few years the railway companies and some businesses were claiming that Canada needed more immigrants to fill agricultural and unskilled jobs. In 1922, the year that "Old Woman" was shown at the RCA, a speaker told the Canadian Club that 500,000 "stalwart peasants" should be brought from Central Europe to work in Western Canada. ${ }^{29}$ Despite the controversy surrounding immigrants, Seiden's painting was admired by art critics, including Albert Laberge who remarked: "Le sujet était rendu avec une vérité et une simplicité qui dénotaient un maître."30
Regina Seiden's portrait Dora (1923) was bought by the National Gallery from the 1923 RCA exhibition. The less familiar Girl Washing Dishes on a Farm, St. Eustache, Quebec (ca. 1923) was painted during a visit to St. Eustache probably in the summer of 1923 (fig. 5). Taken together these paintings suggest something about the complexity of women's situation in the 1920s.

It was now considered acceptable for middleclass women to work before marriage on the grounds that it would make them more self-confident as wives and mothers. ${ }^{31}$ The mass circulation magazines declared that there had never been so many career opportunities for women and popularized an image of the modern woman with a successful career and active social life. Fashion designers created a new look - bobbed hair and short skirts reflecting the career woman's need for simpler styles and more freedom of movement. But after marriage women were expected to give up their careers and become financially and emotionally dependent on their husbands. There were contradictions, as feminist Anne Anderson Perry suggested in 1928, "between old ideals of shrinking, dependent femininity, and the more modern conception of woman as an independent entity with a destiny of her own, both political and economic." 32

Seiden's Dora can be associated with the modern conception of woman. The model, Dora Gidlow, was a young Montreal poet whose work had appeared in Arnerican publications like Pearson's Magazine, edited by Frank Harris. ${ }^{33}$ Seiden presents her in three-quarter view, wearing a short-sleeved blue dress, wide-brimmed hat, and long dangling beads. She sits slightly slumped in her chair, gazing downward as though absorbed in thought. This image of a stylishly dressed female poet links women to the arts, fashion, urban sophistication, and modernity. In style as well as subject the painting can be associated with modernity. The slightly flattened image, bold colours (blue dress against terracotta background), and vigorous brushwork give the work a Post-Impressionist look.

Unlike Dora, who has an identity and a profession, the model in Girl Washing Dishes is a nameless Quebec farm girl performing a routine household chore. She stands with her back to the viewer, further obscuring her identity, her hands plunged in a bowl. The absence of running water suggests the gap in technology between the city and the countryside. While middle-class urban women in the 1920s had the advantage of electric vacuum cleaners and gas stoves, rural women had woodor coal-burning stoves and washed clothes and dishes by hand. ${ }^{34}$ 
Figure 4. Regina Seiden, Dora, 1923. Oil on canvas, $76.5 \times 66.5 \mathrm{~cm}$. Ottawa, National Gallery of Canada. Purchased, 1924 (Photo: National Gallery of Canada).

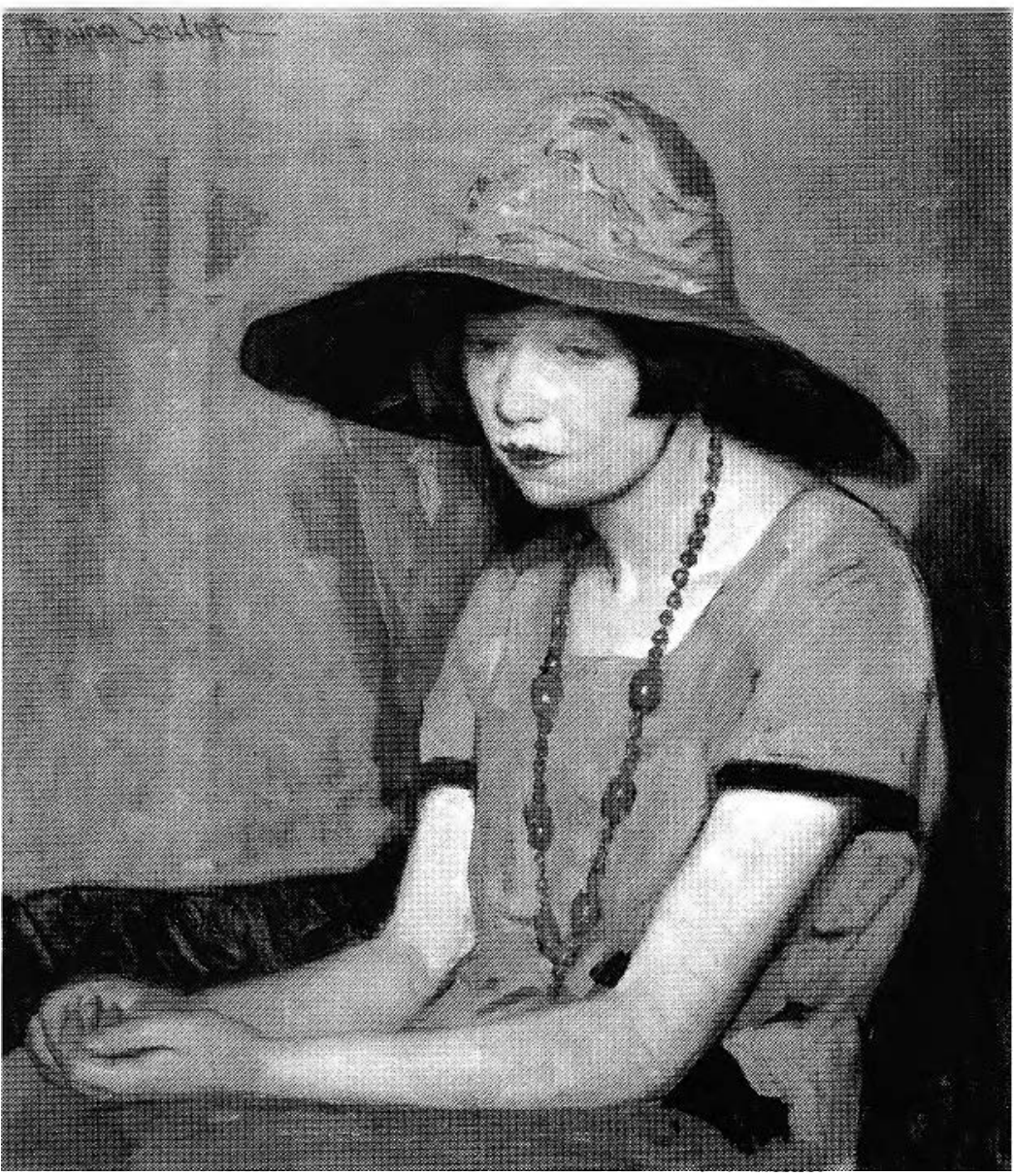

monotonous task in a bare room. The model faces a blank wall broken only by the light-filled window. The girl's hat on the sill, directly in her line of vision, and the light that touches her face, associate her with the outside world and suggest an escape, if only in fantasy, from the dreariness of the kitchen.

The Beaver Hall painter Prudence Heward (1896-1947) focuses more directly on the changing roles of women in works like At the Theatre (1928), Girl on a Hill (1928) and Rollande (1929). A comparison of Rollande (fig. 6) with Girl Washing Dishes suggests that Heward had a somewhat different view of the French-Canadian farm girl. Unlike Seiden's anonymous model, Heward's subject has an identity and strong presence. The largescale figure, cropped below the knees, confronts the viewer boldly, turning her back to the farm. ${ }^{38}$ The model's defiant pose, arms akimbo, and scowling face suggest a rebellion against women's traditional roles and associate her with the girls who were abandoning the farm.

Paintings of women occupy an important place in Seiden's oeuvre. Besides depicting women of various social and ethnic backgrounds, Seiden took a painterly interest in the female body. Nudes, a large and ambitious work, was shown at the National Gallery's Special Exhibition of Canadian Art in 1926 (fig. 7).

The female body was an unusual subject for a

The girl in Seiden's painting is probably the farmer's daughter, or other relative, since Quebec farmers counted on the unpaid labour of their families in the home and fields. ${ }^{35}$

As Montreal became more industrialized around the turn of the century, many young people flocked to the city in search of jobs. In an attempt to stop the exodus, the Quebec Ministry of Agriculture spearheaded the formation of the Cercles de fermières in 1915 to counteract the isolation of farm life and improve women's domestic and agricultural skills. ${ }^{36}$ At the same time, the Ligue nationale de la colonisation, founded in 1916, tried to lure city-dwellers back to the land. Its policies were supported by the Catholic church, whose bishops published a pastoral letter in 1923, promoting colonization. ${ }^{37}$

At first glance, Girl Washing Dishes might seem to reinforce the message about women's traditional roles advocated by church and state. But Seiden's image can be read as a reminder of the isolation and tedium of rural women's lives. Unlike the nineteenth-century English artist Helen Allingham who romanticized rural life in her paintings of women and children in cottage gardens, Seiden focuses on a solitary figure performing a
Canadian woman at that time. ${ }^{39}$ But Seiden may have been prompted to pursue the subject by a favourable review of a nude she showed at the AAM Spring exhibition in 1923. After noting her ability to indicate the form beneath the skin, Laberge remarked: "Il est très rare que l'on voit une étude de nu aussi bien réussi." 40

Nudes represents two women seated on a stone ledge in front of a stylized rocky background. The figures appear to be two studies, side- and front-views, of the same model. The lefthand figure, turned three-quarters towards her companion, sits unselfconsciously, but the pose of the other figure is more contrived. She leans toward her companion, tilting her head slightly back to meet the other's gaze. Given the controversial subject, two naked women looking at each other, it is perhaps surprising that a long review of the exhibition in the Ottawa Citizen makes no reference to Nudes. ${ }^{41}$

Since Kenneth Clark formulated the distinction between the "nude" and the "naked" in his book The Nude: A Study in Ideal Form (1956), art historians have used the terms to categorize different ways of representing the female body. ${ }^{42}$ Before the 
Figure 5. Regina Seiden, Girl Washing Dishes on a Farm, St Eustache, Quebec, ca. 1923. Oil on panel, 31.I x 22.2. cm. Montreal, Montreal Museum of Fine Arts. Gift of Regina Seiden Goldberg, 1975 (Photo: Montreal Museum of Fine Art).

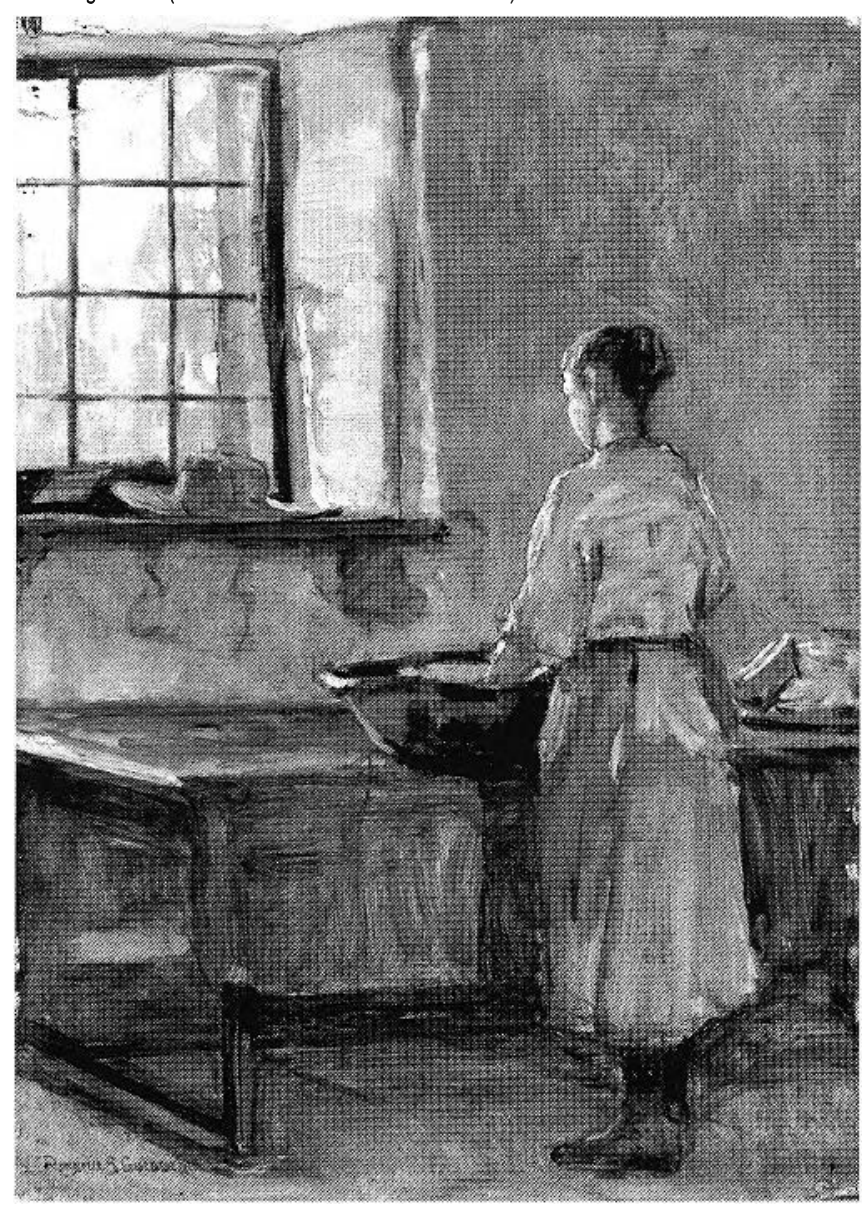

twentieth century, the nude was the more usual mode of representation of the white, female body within western high-art. ${ }^{43}$ To be experienced as art, rather than as pornography, the female body had to be transformed into a suitable object for male aesthetic contemplation. For this purpose a variety of conventions were adopted, including the framing of the body within a mythological or historical context, the idealization of the body, the concealment or erasure of body hair, and the manipulation of the pose, gaze and gestures. ${ }^{44}$ The woman was often represented asleep or with head averted, strategies that rendered her unconscious of the viewer's gaze and invited the viewer (constructed as male) to project his fantasies upon the female body. 45

In an essay entitled "Naked Ladies," published in 1935, Donald Buchanan remarked on "the Puritanical dislike of the human form" that led to the removal of works by Lilias Torrance Newton and Edwin Holgate from the walls of the Art Gallery of Toronto. ${ }^{46}$ Criticism of Newton's Nude in a Studio (1933) focused on the model's fashionable green shoes which disrupt the concept of an ideal female beauty existing outside of time. ${ }^{47}$ Furthermore, Newton breaks with the conventions governing
Figure 6. Prudence Heward, Rollande, 1929. Oil on canvas, $139.9 \times 101.7 \mathrm{~cm}$. Ottawa, National Gallery of Canada. Purchased, 1930 (Photo: National Gallery of Canada).

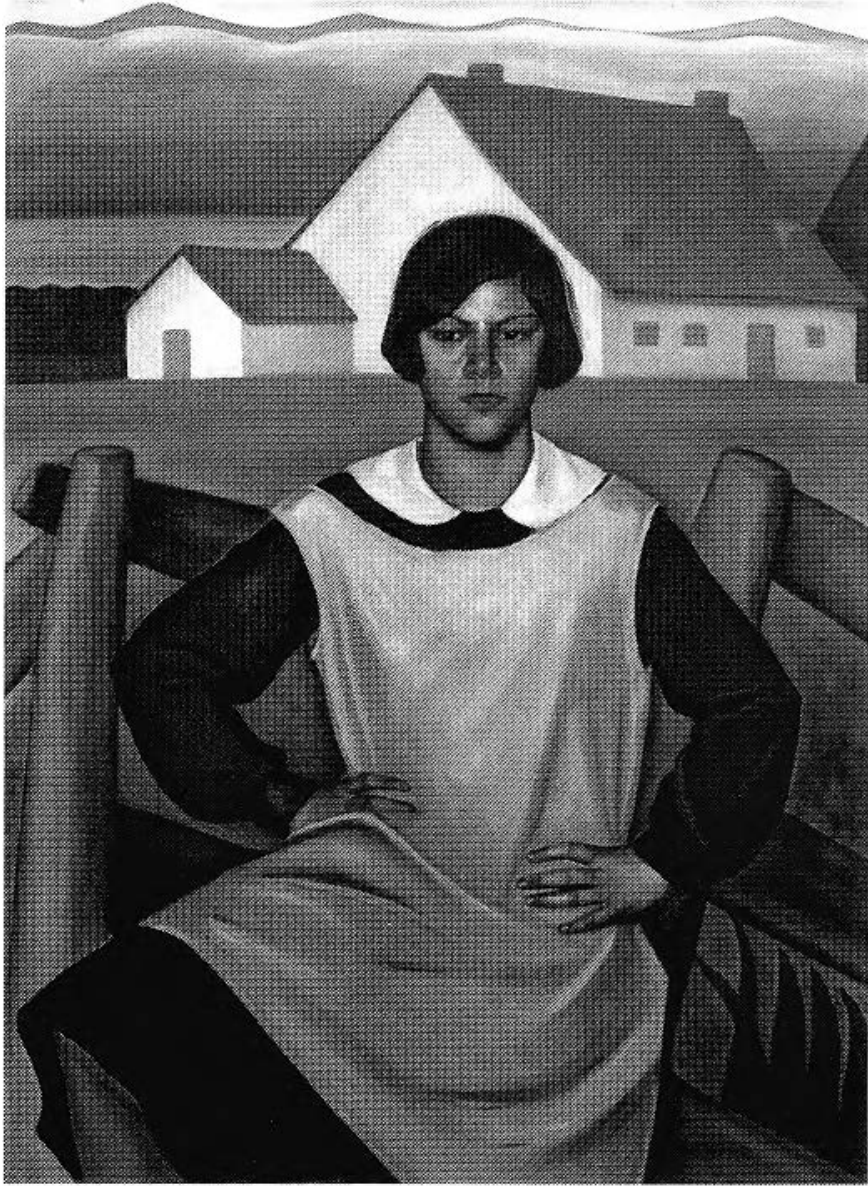

the nude by representing a woman in an active position, standing hand on hip, boldly engaging the viewer's gaze. Nude in a Studio belongs to the category "naked woman" - a category not fully accepted in Canada at that time. Randolph Hewton's Sleeping Woman (1929), which portrays an idealized female body in a passive position, was more in tune with the expectations of the period (fig. 8).

Like Newton, Seiden does not idealize the female body. The right hand figure in Nudes is shown with pubic hair. There are no accessories in Seiden's image to suggest a mythical or narrative setting for the figures; on the contrary, their short "bobbed" hair situates them in the 1920s. Why is it, then, that Seiden's painting did not provoke the controversy that Newton's did?

It could be that Seiden's work, with its stylized outdoor setting, was seen as belonging to a genre, nude in a landscape, that goes back to the Renaissance. Buchanan argues that a nude in an outdoor setring was more acceptable to Canadians because of the symbolic values that landscape painters (i.e. the Group of Seven) were projecting onto the Canadian landscape. ${ }^{48} \mathrm{Or}$ 
Figure 7. Regina Seiden, Nudes, ca. 1925. Oil on canvas, $117.4 \times 91.5 \mathrm{~cm}$. Ottawa, National Gallery of Canada Purchased, 1926 (Photo: National Gallery of Canada).

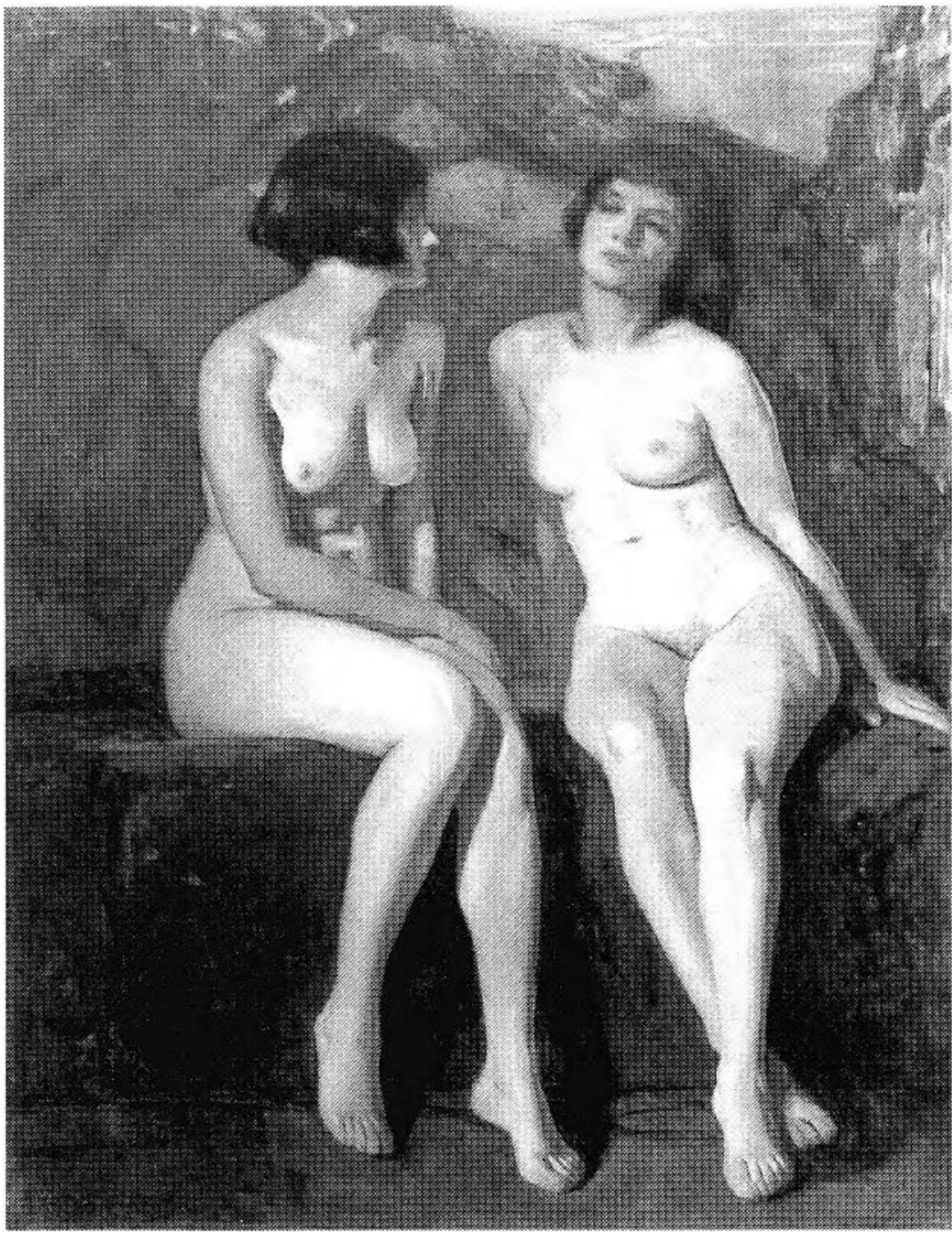

mercial artist in Chicago..$^{50}$ When Seiden met him, he was divorced from his first wife and had just returned from a two-year sojourn in Palestine. Although only half Jewish, Goldberg had a deep attachment to Palestine and to Jewish culture.

Within a few weeks of meeting, Seiden and Goldberg were lovers. Through the winter of 192627 she worked in her own studio-apartment, seeing Goldberg every evening. In her memoir, Seiden suggests that Goldberg would have liked to continue the liaison indefinitely, but she knew that her family would disapprove of such an arrangement. She returned to Montreal in September 1927. Goldberg finally agreed to the marriage, which took place in Montreal on 5 June 1928.

Seiden and Goldberg spent the first seven months of their married life in Palestine, where they borh painted. Forced to leave because of mounting violence between Arabs and Jews, the couple setcled in Paris. Here they rented a large studio with the understanding that he would paint at one end and she at the other. But within a few months she stopped painting.

In her memoir, Seiden dismisses the question of her aborted career in a few lines. She could not work in the same studio as her husband, but when she joined a class, she felt guilty because she was not cooking his meals. She concludes: "I only blame myself. I just wanted to live for him, he was very good to me and we loved being together all the time."

Seiden's remarks underline the importance of personal space for the creative woman. During her perhaps viewers regarded Nudes as merely an academic exercise. It is also possible that the Art Gallery of Toronto, which banished the paintings by Newton and Holgate, had more timid trustees and a more puritanical public than the National Gallery.

After selling Nudes for $\$ 500$, Regina Seiden returned to Paris. Her year-long stay was financed by her brothers and by sales of her work, including a series of "ancestral portraits" commissioned by the Taschereau family. She used photographs and, as requested, executed each work in the style of the period, leaving them unsigned. ${ }^{49}$

In Paris, Seiden attended a dinner in honour of a Hebrew poet at which she met Eric Goldberg. Born in Berlin in 1890, the son of a German portrait painter, Goldberg had built up an international reputation as a painter and teacher. He had taught at the Bezalel Art School in Jerusalem (1911-15) and at the Berlin Academy of Art (1916-20), besides working as a comliaison with Goldberg, Seiden had her own studio, hired her own models, and was, by her own admission, "very productive." On her return to Montreal, she exhibited three works at the RCA and three at the AAM Spring Exhibition, most of which were executed abroad. After the marriage she no longer had a studio. She had no painter friends to encourage her, unlike the Beaver Hall women who were spurred to exhibit by friendly rivalry. Nor did Seiden have much support from her husband, who according to Antonia Robinson, would never have asked his wife to stop painting but was content with her decision.

Seiden's retirement has to be considered in the context of the period and of her personal history. Brought up in a traditional Jewish household, and educated in a Catholic convent, Seiden internalized the patriarchal model of marriage. Wives were expected to devore themselves to their families - and most had little choice since school boards and other institutions would not employ married women. ${ }^{51}$ Although painters were 
Figure 8. Randolph Hewton, Sleeping Woman, ca. 1929. Oil on canvas, $102.0 \times 153 \mathrm{~cm}$. Ottawa, National Gallery of Canada. Purchased, 1930 (Photo: National Gallery of Canada).

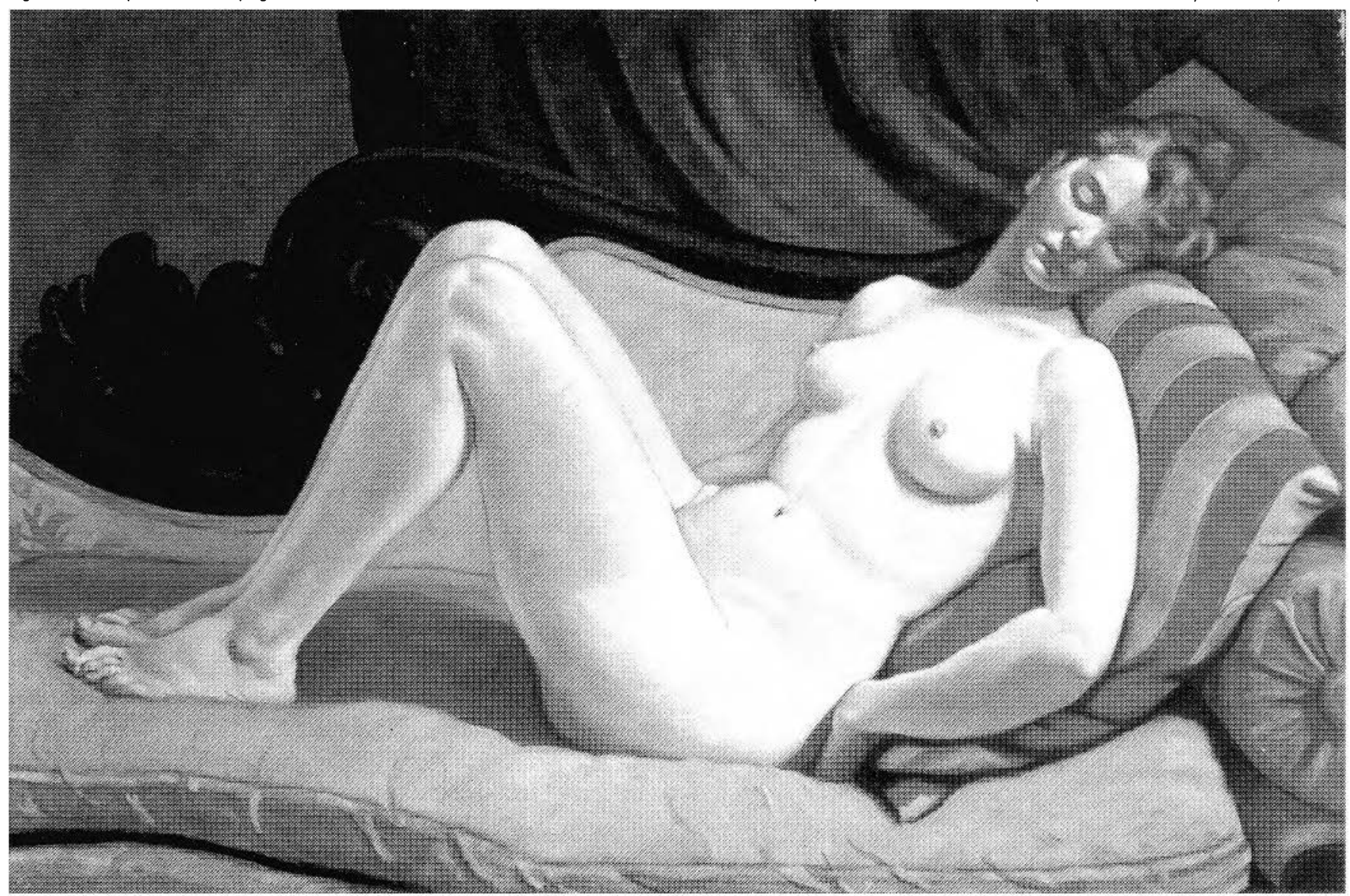

in a different position, being self-cmployed, many found it difficult to combine domestic and professional responsibilities. A few Canadian women painters, such as Jori Smith (b. 1907) and Marian Dale Scott (1906-93), married, but most of the professional women painters of Seiden's generation stayed single, including all the Beaver Hall women except Lilias Torrance Newton. ${ }^{52}$

Regina Seiden was twenty-nine when she met Eric Goldberg and, according to Antonia Robinson, had never had a romantic attachment. At the convent school and at the AAM, Seiden was an outsider. In Paris, snubbed by the French students at the Académie Julian, and separated from her family, Seiden must often have felt isolated. ${ }^{53}$ All that changed when she met Eric Goldberg. Not only was he an attractive, amusing companion, but he also introduced her to a wide circle of artists and intellectuals, many of them Jewish emigrés. For perhaps the first time in her life, Seiden may have felt as though she belonged.

Regina Seiden decided there could only be one professional artist in the family. She stopped exhibiting. ${ }^{54}$ She and Goldberg had what Hanna Papanek observed among American professional couples and labelled the "two-person single career." 55
Seiden relieved her husband of all domestic responsibility so that he could do what he loved most - paint. She found her pleasure in his companionship and in the rich cultural life of Paris. Her memoir paints a vivid picture of the celebrities they met (Chagall, the sculptor Chana Orloff, psychiatrist Otto Rank), theatres they attended, and places visited - especially a sojourn in the artists' colony at Tossa del Mar in Spain.

During their years in Europe, they spent their summers with Seiden's family in Montreal. In 1935, realizing that Europe was on the verge of war, they gave up their home in Paris. All the work that Seiden had done before and just after her marriage was left behind; they were hoping to return.

The first few years in Montreal were very difficult. Canada was still suffering from the Depression, and artists across the country were having trouble making a living. Seiden may have been able to help her husband through her acquaintance with Montreal artists like Marian Dale Scott and John Lyman. Both Seiden and Goldberg were members of the Contemporary Art Society (1940-48), founded by Lyman to bring together the city's more progressive painters. ${ }^{56}$

Needing some financial stability, Seiden and her husband 
Figure 9. Regina Seiden Goldberg, Portrait of South American Girl, 1927. Oil on canvas, $74.0 \times 61.5 \mathrm{~cm}$. Oshawa, Robert Mclaughlin Gallery. Purchased from the artist, 1989 (Photo: Thomas Moore).

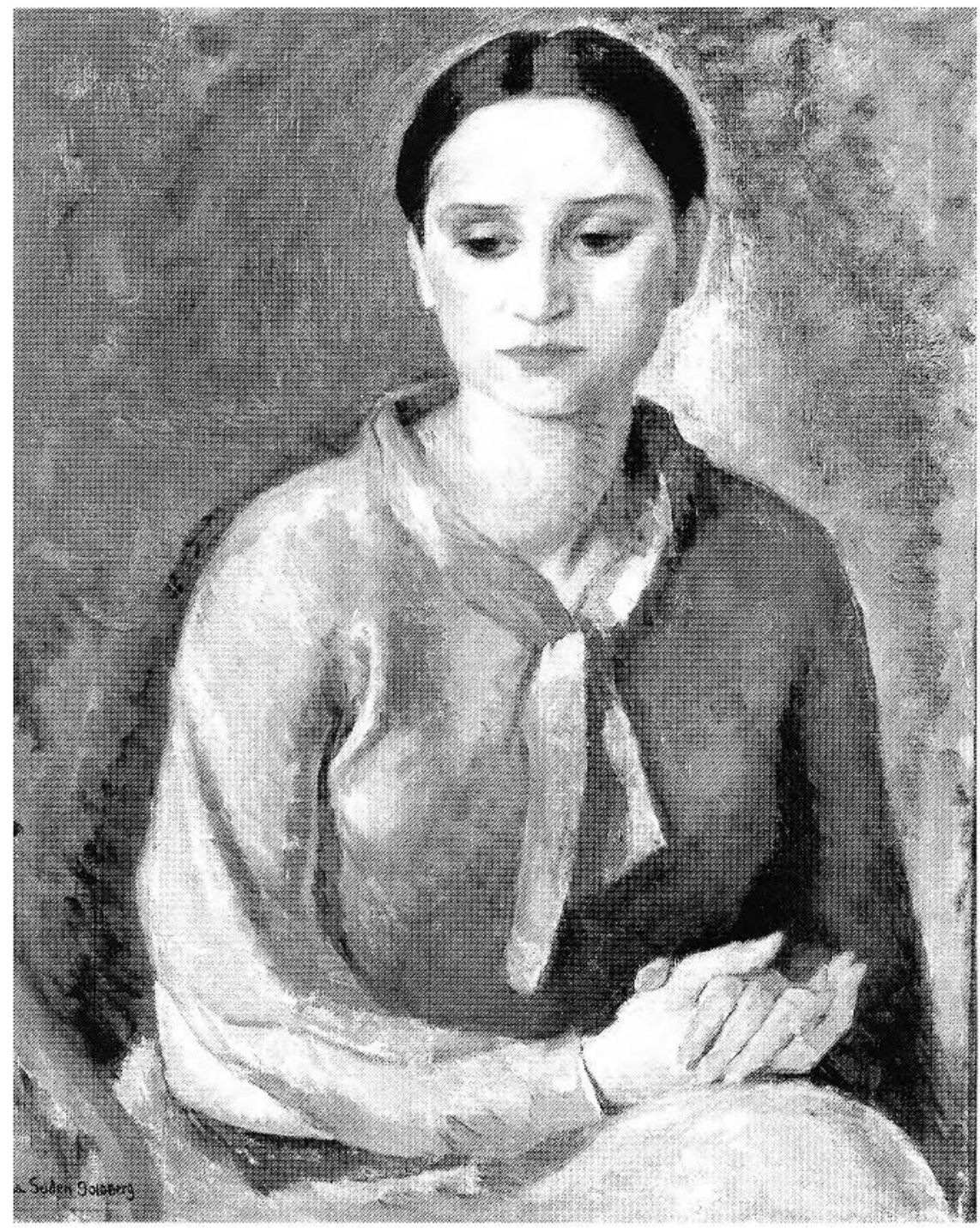

dating from the 1920s. ${ }^{58}$ Portrait of South American Girl (1927), which Seiden later sold to the Robert McLaughlin Gallery, was probably included (fig. 9). ${ }^{59}$ Although the canvas was painted before her marriage, Seiden has added "Goldberg" to her signature, perhaps in an attempt to reconnect herself to her former identity.

For South American Girl, Seiden chose a model from a minority group, as she had done on several previous occasions. In 1925 she exhibited Une Polonaise at the Royal Canadian Academy, and in 1926 Two Sisters from Kiev at the AAM Spring Exhibition. It may be that her experiences as a Jewish girl in a French-Canadian community and at Roman Catholic schools led her to empathize with the outsider.

The model in South American Girl sits facing the viewer with hands folded and eyes downcast. As though to contradict the stereotype of the Latin American girl (brilliant colours, swirling petticoats, tango dancer), Seiden's image of a simply dressed young woman conveys a fecling of stillness and serenity. The model's dress and the background are executed in subtle tones of yellow and green, with ripples of darker green for the shadows.

Marian Dale Scott, who combined the roles of professional painter and wife to lawyer-poet Frank Scott, told me of a chance encounter with Regina Seiden after Goldberg's deach. "Now that I am a widow, I'm starting to paint again," Seiden said.

started an art class at the Shaar Hashomayim Synagogue in Westmount. For twenty years, 1949-69, Seiden helped her husband with the teaching and handled all the administrative work. Paying tribute to her in an end-of-term speech, Goldberg said: "In one word I could not do without her, in the class or at home." 57

When Goldberg died, on 17 February 1969, Seiden suffered a complete breakdown and had to be hospitalized. It took months of therapy to reconcile her to the prospect of living for herself. A psychiatrist encouraged her to start painting again.

On her recovery, Seiden reopened the art class at the Shaar Hashomayim. Teaching helped rekindle her belief in herself as an artist. In April 1976, she had an exhibition in the library of the Synagogue, but the paintings shown were mostly small oils,
But as Scott remarked, it is difficult to start again after so long a gap. ${ }^{60}$

Seiden was 71 when her husband died. Although she tried to paint, and completed several portraits, she lacked the energy and motivation of her youth. Writing to her friend Judy King from Rockport, Massachusetts, Seiden said: "This place is most picturesque. All I need is to have ten years at least reduction of my age. I might then have done something about it, but now it's too much effort." 61

In 1976, she gave up teaching and used the proceeds from the sale of Goldberg's work to buy a condominium in Florida, where she spent the winters. ${ }^{62}$ Ten years later she broke her hip. Although old and frail, she insisted on staying in the home that she had shared with her husband, surrounded by his paintings and books. Seiden died on 11 January 1991, aged ninety-three. 
As a widow, Seiden had continued her efforts to secure Goldberg's place in history. According to Judy King, Seiden bristled at any suggestion that she was a more talented painter than her husband. ${ }^{63}$ She had given up her career for him and needed to believe that the sacrifice was worthwhile. Privately, she treasured the complimentary reviews and letters she had received in her youth, pasting them in her scrapbook. When the new National Gallery was completed in 1988, Judy King took her to the opening. Dora was on display. Ignoring all the celebrities and the lavish buffet, Seiden sat in her wheelchair rediscovering her early portrait.

Since the Second World War, Canadian artists like Molly Lamb Bobak and Mary Pratt have managed to combine professional careers with marriage and child rearing. It is never easy, as Sandra Gwyn suggests in her essay on Mary Pratt, another woman painter who, like Seiden, married a fellow painter. ${ }^{64}$ Regina Seiden's career reminds us how much more difficult it was for women of an earlier generation, who often felt pressured by society to choose between marriage and a career.

\section{Notes}

1 See Laurier Lacroix et al., Peindre à Montréal, 1915-1930: Les peintres de la Montée Saint-Michel et leurs contemporains, exh. cat., Galerie de l'UQAM (Montreal, 1996), 50 and 54.

2 See Press Comments on the Canadian Section of Fine Arts, British Empire Exhibition, 1924-25 (Ottawa, n.d.); and Ann Davis "The Wembley Controversy in Canadian Art," Canadian Historical Review, LIV, 1 (March 1973), 71-72.

3 Between 1919 and 1926 the National Gallery bought three works by Mabel May (1877-1971), two by Kathleen Morris (18931986) and three by Lilias Torrance Newton (1896-1980).

4 Albert Laberge, "Travaux de sculpture au Salon du Printemps," La Presse, 31 March 1924, 22.

5 See Deborah Cherry, Painting Women: Victorian Women Artists (London, 1993), 32-44.

6 Personal information about Seiden was provided by her sister, the late Antonia Robinson, in two interviews, 6 and 13 February 1991.

7 See Marie-Paule Malouin, Ma soeur à quelle école allez-vous?: Deux écoles de filles à la fin du XIXe siècle (Montreal, 1985), 88.

8 Malouin, Ma soeur, 96.

9 See Seiden's autobiographical notes (autograph ms., n. pag.), Goldberg/Seiden collection, Canadian Jewish Congress National Archives (CJCNA), Montreal, hereafter "Memoir." The exhibition which Seiden saw at the Art Association may have been the popular Exposition d'Art Français (19 January-1 March 1909), which attracted 7,502 visitors.

10 Arthur H. Calvin, "Anne Savage, Teacher," M.A. Thesis, Sir George Williams University, 1967, transcript of taped interview, 3.

11 The fees at the AAM school were $\$ 40$ a session, $\$ 25$ a term, or $\$ 10$ a month. See AAM Annual Report, 1915.
12 See Lacroix et al., Peindre à Montréal, 62.

13 Sce Janet Brooke, Discerning Tastes: Montreal Collectors, 18801920, exh. cat., Montreal Museum of Fine Art (Montreal, 1989) for an inventory of nineteenth-century European paintings in Montreal collections between 1880 and 1920 .

14 For example, in 1916 Brymner gave a public lecture on "Modern Isms in Art." See AAM Annual Report, 1916, 15.

15 See Griselda Pollock, Vision and Difference: Femininity, Feminism and the Histories of Art (London, 1988), 11.

16 The Beaver Hall women also include Mabel May, Mabel Lockerby, Nora Collyer, Ethel Seath and Emily Coonan. For the relationship between the Beaver Hall Group (1921-22) and the women's group that emerged from it, see Barbara Meadowcroft, Painting Friends: The Beaver Hall Women Painters (Montreal, 1999), 60-67.

17 See "Public Profession of Arristic Faith: Nineteen painters Represented in 'Beaver Hall Group's' Exhibition," Montreal Gazette, 18 January 1921, 5; and "Des Artistes Qui Affirment de Beaux Dons," La Presse, 21 January 1922, 2. Seiden was in Paris when the 1922 exhibition was held.

18 Sarah Robertson's brother was killed in the First World War, as were Annc Savage's twin brother and two of Lilias Torrance Newton's brothers.

19 See Edmond Dyonnet to Homer Watson, president of the RCA, 29 December 1919, Regina Sciden Goldberg file, Narional Gallery of Canada.

20 The Canadian War Memorials Exhibition (the Home Front) was shown at the Art Gallery of Toronto in October 1919.

21 See Kristina Huneault, "Herocs of a Different Sort: Gender and Patriotism in the War Workers of Frances Loring and Florence Wyle," Journal of Canadian Art History, XV, 2 (1993), 27-45, esp. 28-29.

22 See Huncault, "Heroes," 34-38.

23 Toronto Evening Telegram, 20 October 1919, as quoted in Huneault, "Heroes," 38.

24 Judy King, interview with Regina Sciden, 14 August 1979, audiotape, kindly loaned to me by the interviewer.

25 Albert Laberge, "Causerie en marge du Salon du Printemps," La Presse, 3 April 1923, 10. There is a copy of the review in Seiden's scrapbook, Goldberg/Seiden collection, CJCNA.

26 A reader has drawn my attention to Marie Hewson Guest's portrait, Ukrainian Girl (ca. 1927-28). Unlike Old Immigrant Woman, Guest's image of her housekeeper dressed in ethnic costume suggests a tendency to objectify the ethnic subject as picturesque other. See Claudine Majzels, "Constructing the Woman Artist: Marie Hewson Guest in Winnipeg," Manitoba History, XXIX (Spring 1995), 2-10.

27 See "Young Artist Honored," Canadian Jewish Review, 7 December 1923, 5; and Paul-André Linteau, Histoire de Montréal depuis la Confédération ([Montréal], 1992), 161-62.

28 See Donald Avery, "Dangerous Foreigners": European Immigrant Workers and Labour Radicalism in Canada, 1896-1932 ([Toronto], 1979), 90.

29 Avery, "Dangerous Foreigners," 98-99.

30 Laberge, "Causerie." 
31 See Mary Vipond, "The Image of Women in Mass Circulation Magazines in the 1920s," The Neglected Majority, ed. Susan Mann Trofimenkoff and Alice Prentice (Toronto, 1977), 116-24, esp. 118.

32 Anne Anderson Perry, "Is Woman's Suffrage a Fizzle?", MacLean's, XII (1 February 1928), 7, as quoted in Vipond, "The Image of Women," 124.

33 Dora Gidlow and her sister, Elsa, a journalist and poet, were friends of Seiden's. See Elsa Gidlow, Elsa: I Come With My Songs (San Francisco, 1985), in which Dora is called Thea. I am indebted to Line Chamberland for calling my attention to this book.

34 See Clio Collective, Quebec Women: A History, trans. Roger Gannon and Rosalind Gill (Toronto, 1987), 234.

35 Until 1931, only $10 \%$ of farm labourcrs were wage earners in Quebec, compared to $17.1 \%$ in Ontario. See Clio Collective, Quebec Women, 233.

36 See Clio Collective, Quebec Women, 236-37.

37 See Clio Collective, Quebec Women, 235.

38 See Natalie Luckyj, Expressions of Will: The Art of Prudence Heward, exh. cat., Kingston, Agnes Etherington Art Centre (Kingston, 1986), 59.

39 Prudence Heward's Girl Under a Tree (1931) is the earliest nude by a woman cited in Jerrold Morris, The Nude in Canadian Painting (Toronto, 1972).

40 Laberge, "Causerie."

41 See E.W. H[arrold], "National Character Seen in Exhibition of Canadian Art," Ottawa Citiizen, 22 January 1926, 12.

42 See Kenneth Clark, The Nude: A Study in Ideal Form (New York, 1956), 3. For a feminist critique of Clark, see Lynda Nead, The Female Nude: Art, Obscenity and Sexuality (London, 1992), 5-33.

43 For the representation of the black female nude in western art, sec Charmaine Nelson, "Coloured Nude: Fetishization, Disguise, Dichotomy," RACAR (Revue d'art canadienne/Canadian Art Review), XXII, 1-2 (1995), 97-107.

44 See Nelson, "Coloured Nude," 101.

45 See Gill Saunders, The Nude: A New Perspective (Cambridge, 1989), 21-26.
46 Donald W. Buchanan, "Naked Ladies," Canadian Forum, XV (April 1935), 273-74. The jury accepted Newton's Nude in a Studio for the Canadian Group of Painters exhibition in 1933, but the Art Gallery of Toronto refused to hang it. Holgate's Nude (1930), bought by the same gallery, was banished to the cellar.

47 See Luckyj, Expressions of Will, 61-63. Luckyj reproduces Newton's Nude in a Studio, which is in a private collection.

48 See Buchanan, "Naked Ladies," 273.

49 See Seiden's scrapbook, Goldberg/Seiden collection, CJCNA.

50 See undated autograph note by Eric Goldberg, Goldberg/Seiden collection, CJCNA; and Robert Ayre, "Montreal Loses 'Old School' Artist," Montreal Star, 19 February 1969, 95.

51 See Vipond, "The Image of Women," 118.

52 See Meadowcroft, Painting Friends, 80-96.

53 Judy King, interview with Seiden.

54 Seiden exhibited at the AAM Spring Exhibition for the last time in 1930, showing A Palestinian (ca. 1929).

55 Hanna Papanek, "Men, Women and Work: Reflections on the Two-Person Career," Changing Women in a Changing Society, ed. Joan Huber (Chicago, 1973), 90-110.

56 Seiden may have contributed to the 1944 Contemporary Art Society exhibition. See Chris Varley to Seiden, 19 October 1979, Goldberg/Seiden collection, CJCNA.

57 Autograph document by Goldberg, dated 1957, Goldberg/Seiden collection, CJCNA.

58 Interview with Terry Lightman, the librarian at the Shaar Hashomayim Synagogue in the 1970s.

59 This work was exhibited at the 1927 RCA exhibition as Argentine Girl.

60 Interview with the late Marian Dale Scott, 19 October 1989.

61 Seiden to Judy King, postcard, 15 July 1974, private collection.

62 Max Stern held a posthumous exhibition for Goldberg at the Dominion Gallery in 1971, and he bought works by Goldberg which he left with Seiden until her death.

63 Interview with Judy King, 6 March 1991.

64 See Sandra Gwyn, introduction, Mary Pratt (Toronto, 1989), $1-21$. 